\title{
Actus salvadoricus B aqri and J airajpuri (Mononchida: Mylonchulidae) from J apan with comment on the phylogenetic position of the genus Actus based on 18S rDNA sequences
}

\author{
Majid Olia ${ }^{1,2}$, Wasim A hmad ${ }^{3}$, Masaaki A raki ${ }^{1}$, Nobuhiro M inaka ${ }^{1}$, \\ Hirosuke Oba ${ }^{1,4}$ and Hiroaki Okada ${ }^{1}$
}

\begin{abstract}
The nematode genus A ctus belonging to the order Mononchida, an important group of predatory nematodes, is rare in the world. Actus salvadoricus Baqri and Jairajpuri, 1974, which had been described from El Salvador, were found from subtropical forest in the northern part of Okinawa Island, Japan. Its morphological observation is made herein and its phylogenetic position is elucidated based on $18 \mathrm{~S}$ rDNA sequence. A. salvadoricus collected from Okinawa is characterized by having its buccal cavity with a moderately developed dorsal tooth, vertical subventral plates with a single row of denticles arranged as 3:3 or 3:4 or 2:4 on two plates, distinct excretory pore, el ongate-conoid ventrally arcuate tail, with tandem caudal glands and terminal spinneret. Based on the nearly complete $18 \mathrm{~S}$ rDNA sequence data already known and revealed in this work, phylogenetic trees of Mononchina were constructed using parsimony and maximum likelihood algorithms. The results show that the genus A ctus forms a sister group with the species of the genus $M$ ylonchulus in the suborder Mononchina, showing the valid status of its taxonomic group. Jpn. J. Nematol. 38 (2), 57-69 (2008).
\end{abstract}

Key words : taxonomy, new record, Okinawa Island, phylogenetic tree, primers for PCR.

\section{INT RODUCTION}

Nematodes of the order Mononchida Jairajpuri, 1969 are all predaceous in nature and play an important role in regulating nematode population in the soil ecosystem (Vairajpuri and Khan, 1982). Not much is known about the mononchid fauna of Japan. Imamura (1931), Kaburaki (1933), Yokoo and Koga (1966),

\footnotetext{
${ }^{1}$ National Institute for A gro-E nvironmental Sciences, T sukuba, Ibaraki 305-8604, Japan.

${ }^{2}$ Department of Plant Protection, Shahrekord University, P.O.Box 115, Shahrekord, Iran.

${ }^{3}$ Department of Zoology, A ligarh Muslim University, A ligarh, 202 002, India.

${ }^{4}$ Research T eam for Detection and Identification of Plant Pathogens and Nematodes, National A gricaltural Research Center, T sukuba, Ibaraki 305-8666, Japan.
}

Shishida (1998), Nakazawa (1999) and Khan et al., $(2000,2002)$ described several species of mononchs but still the information is scanty. A $n$ intensive survey was conducted in various parts of this country to investigate the mononchid fauna. A mong the several genera recorded, we recognized a population belonging to the rare genus A ctus Baqri and Jairajpuri, 1974 from Y ona field subtropical forests in Okinawa Island. W ith precise observations it was identified as A. salvadoricus Baqri and Jairajpuri, 1974.

Genus A ctus consists of only four known species, A. minutus (Mulvey, 1963), the type species, from Saipan and Truk, North Pacific, A. salvadoricus Baqri and Jairajpuri, 1974 from EI Salvador, Central A merica, A. nanurus Siddiqi 
(1984) from Fiji, South Pacific and A. neocaledonensis Y eates, 1992 from New Caledonia. A ny other records of this genus were not known except the original description of each species. The original description of $A$. salvadoricus was inadequate from the recent points of view as well as the others were. Here we decided to ascribe several morphological characters of $A$. salvadoricus.

Recently, DNA -based techniques have provided an attractive tool to help clearing up the controversial opinions in nematode taxonomy. The nematode DNA cistron typically consists of several hundred tandemly repeated copies of the transcribed units (small subunit or SSU or 18S; large subunit or LSU or 28S; 5.8S; internal transcribed spacer or ITS and external transcribed spacer) and an external non-transcribed or intergenic spacer (NTS) (Hill and Dixon, 1991). The highly conserved sequences (18S and 28S), and highly variable spacer sequences (NTS and ITS) are considered most useful for phylogenetic inference between very distantly related species for the former, and very closely related species for the latter (Page and Holmes, 1998). In the present study, we have also attempted to assess the molecular phylognetic position of this rare nematode genus, viz a viz other closely related genera in the suborder Mononchina Kirjanova and Krall, 1969 using 18S rDNA sequence data.

\section{MATERIALS AND METHODS}

Nematode extraction:

The nematodes were isolated from the soil samples collected from evergreen forest by Cobb's sieving and decantation (Cobb, 1918) and modified Bearmann's funnel technique (Southey, 1970). Specimens obtained in water were killed by pouring equal quantity of boiling TAF, dehydrated by slow method and mounted in anhydrous glycerin (Seinhorst, 1962). M easurements were taken with an ocular micrometer and draw- ings were made using drawing tube mounted on a Nikon Optiphot 2 research microscope. LM photographs were taken using Olympus digital camera CS230B operated through Dell Precision 370 personal computer.

DNA extraction:

A single nematode was transferred to $1 \mu \mathrm{l}$ $\mathrm{dH}_{2} \mathrm{O}$ in a $0.2 \mathrm{ml}$ flat top-PCR tube cap, crushed with a sterile needle and then $10 \mu$ of worm lysis buffer (Orui (1996): $10 \mathrm{mM}$ Tris-HCl: $\mathrm{pH}$ 8.0, 1 mM EDT A, 1\% IGEPAL CA-630 (Sigma, USA) and $100 \mu \mathrm{g} / \mathrm{ml}$ Protainase $\mathrm{K}$ ) was added. The cap and a tube were connected, and the mixture was shifted into the tube with centrifuge. Tubes were frozen at $-45^{\circ} \mathrm{C}$ for at least one hour, incubated at $65^{\circ} \mathrm{C}(2 \mathrm{hr})$, and $95^{\circ} \mathrm{C}(10 \mathrm{~min})$ consecutively. After incubation, tubes frozen at $-45^{\circ} \mathrm{C}$ for at least one hour and used for PCR. DNA samples were stored at $-45^{\circ} \mathrm{C}$ until further use. PCR:

The PCR reaction mixture contained $2.5 \mathrm{U}$ per $100 \mu \mathrm{l}$ Prime Star Polymerase HS (T akara, Ortsu, JAPAN), $1 \times$ PCR buffer manufacture, $0.2 \mathrm{mM}$ dNTPs and $0.5 \mu \mathrm{M}$ each primer. Genomic DNA, $0.5 \mu$, was used directly as template for PCR in $25 \mu$ of the reaction mixture. $A$ negative control without template DNA was included in each amplification. The forward primer EukF (10) and the reverse primer EukR (10) (Delong, 1992) were used in the PCR (T able 1) which covers nearly the entire area of $18 \mathrm{~S}$ rDNA. The PCR 185 amplification profile performed on PT -800 thermal cycler (A STEC, Japan) consisted of $3 \mathrm{~min}$ at $98^{\circ} \mathrm{C}$; 32 cycles of 10 $\mathrm{sec}$ at $98^{\circ} \mathrm{C}, 15 \mathrm{sec}$ at $59^{\circ} \mathrm{C}$ and $2.5 \mathrm{~min}$ at $72^{\circ} \mathrm{C}$, followed by a final step of $10 \mathrm{~min}$ at $72^{\circ} \mathrm{C}$. Primers 664 and 665 (T able 1) were used for ITS amplification (V rain et al., 1992) which covers ITS1, IT S2, 5.8S and small portions of $18 \mathrm{~S}$ and 28S. The PCR ITS amplification program consisted 3 min at $98{ }^{\circ} \mathrm{C}, 28$ cycles of $10 \mathrm{sec}$ at $98{ }^{\circ} \mathrm{C}$, $15 \mathrm{sec}$ at $54{ }^{\circ} \mathrm{C}$ and $1 \mathrm{~min}$ at $72{ }^{\circ} \mathrm{C}$, followed by a 
Table 1. Oligonucleotide used in this study for PCR and to elucidate 18S / IT S rDNA sequences.

\begin{tabular}{|c|c|c|}
\hline Oligo name & Primer sequence $\left(5^{\prime}-3^{\prime}\right)$ & Sense \\
\hline${ }^{1}$ EukF (10) & AACCT GGT T GAT CCT GCCAGT & Forward \\
\hline${ }^{2}$ SSU18A & AAAGATTAAGCCATGCATG & Forward \\
\hline $39 F X$ & AAGT CT GGT GCCA GCA GCCGC & Forward \\
\hline $324 \mathrm{~F} 1$ & AGAGGTGAAATTCTTGGATC & Forward \\
\hline${ }^{3} 2 \mathrm{FX}$ & GGA AGGGCACCACCAGGAGT GG & Forward \\
\hline${ }^{2}$ SSU23F & ATTCCGATAACGAGCGAGA & Forward \\
\hline${ }^{4} 664$ & TTGATTACGT CCCT GCCCTTT & Forward \\
\hline${ }^{5} \mathrm{C} 18$ & GTTTCCGTAGGT GAACCTGC & Forward \\
\hline${ }^{2}$ SSU9R & AGCT GGAATTACCGCGGCTG & Reverse \\
\hline${ }^{2}$ SSU26R & СAT TCT T GGCAA AT GCTTTCG & Reverse \\
\hline 2 SSU23R & TCT CGCT CGT TAT CGGA AT & Reverse \\
\hline${ }^{1}$ EukR (10) & TGAT CCT T CT GCAGGT T CACCTAC & Reverse \\
\hline${ }^{4} 665$ & TTTCACT CGCCGTTACTAAGG & Reverse \\
\hline${ }^{5} \mathrm{C} 26$ & ATATGCTTAAGTTCAGCGGGT & Reverse \\
\hline
\end{tabular}

Sources: ${ }^{1}$ Delong (1992) ${ }^{2}$ Blaxter et al. (1998) ${ }^{3}$ M eldal et al. (2007)

${ }^{4}$ Vrain et al. (1992) ${ }^{5}$ Curran et al. (1994)

final step of 10 min at $72{ }^{\circ} \mathrm{C}$. A mplified PCR product, $5 \mu$, was electrophoretically fractionated in $1 \times$ TAE buffer in $2 \%$ agarose gel and visualized by staining with ethidium bromide. Gels were viewed on a UV transilluminator. The remaining PCR product stored at $-45^{\circ} \mathrm{C}$ for further use.

DNA Sequencing:

PCR products, $2 \mu l$, were purified with the 40 times diluted ExOSA P-IT ${ }^{\circledR}$ (USB Co., USA) 3 $\mu l$, by incubating the mixture for $90 \mathrm{~min}$ at $37^{\circ} \mathrm{C}$, followed by enzyme inactivation for $10 \mathrm{~min}$ at $80^{\circ} \mathrm{C}$. Purified PCR products were used for DNA sequencing using $A B I$ PRISM 3100 Genetic A nalyzer (A pplied Biosystems, USA) with a reaction kit (Big Dye Terminator Cycle
Sequencing Ready Reaction Kit ver. 3.1, A pplied Biosystems, Japan). In addition to the amplification primers, other sequencing primers ( $T$ able 1 ) were also used to ensure proper overlapping of fragment products from both strands to obtain sequences of nearly entire $18 \mathrm{~S}$ and complete IT S rDNA regions (Fig. 1). Phylogenetic A nalysis:

DNA sequence data from various primers were assembled using GENETYX-WIN version 1.03 (Software Development, Japan). Multiple alignments of the known and new sequences of 18S rDNA were performed in ClustalX version 1.8 (Thompson et al., 1997) with default parameter settings and further edited manually. All phylogenetic trees were constructed in PA UP* version 4.0b10 (Swofford, 2002) using maximum parsimony (MP) and maximum likelihood (ML) criteria. MP analysis used the heuristic search option with tree bisection-reconnection (TBR) branch swapping with 10 random sequence additions of taxa. Gaps were scored as "missing". ML analysis was also performed using the heuristic search option with TBR branch swapping and 10 random sequence additions of taxa. The most appropriate model of sequence evolution for our $M L$ analysis was selected using the A kaike Information Criterion (AIC) as implemented in Modeltest version 3.7 (Posada and Crandall, 1998). Support for each internal branch of the optimal trees was assessed via

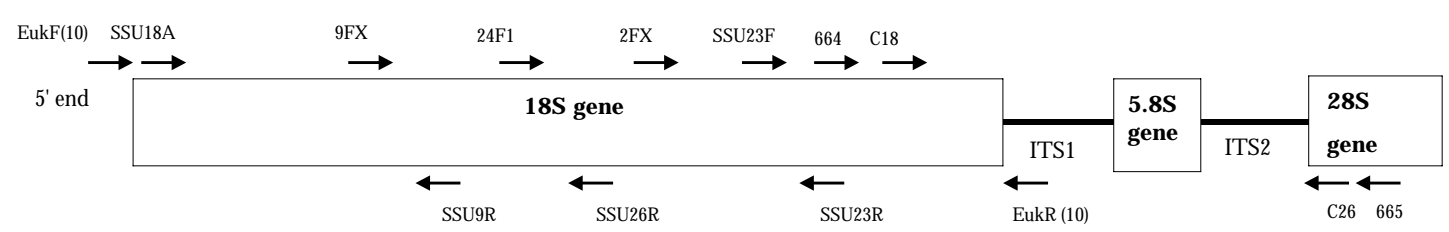

Fig. 1. Schematic diagrame showing relative positions of the primers for PCR and sequencing primers to provide data from $18 S$ and ITS rDNA segments. Sizes are approximate not to the scale. 
1,000 nonparametric bootstrap replicates in PA UP*. Phylogenetic trees were examined using TreeV iew (Page, 1996) and converted into graphic file for A dobe Illustrator 9 (A dobe Systems Inc., USA ).

\section{RESULTS}

\section{Actus salvadoricus Baqri and J airajpuri, 1974}

M easurements: See T able 2.

Morphology (Fig. 2 and 3):

Females ( $n=3$ ): Body slightly curved ventrad upon fixation. Cuticle smooth, 2-3 $\mu$ m thick along the body. Lateral chords about one-third of body width at mid body. Lateral, dorsal and ventral body pores indistinct. Lip region offset, distinctly wider than adjoining body, about three times as wide as high and about half as wide as body width at neck base. Labial papillae projecting slightly above labial contour. A mphids cup-shaped with slit-like aperture, slightly anterior to the dorsal tooth apex. Buccal cavity thick-walled, barrel-shaped, slightly narrow at base, about 1.9-2.0 times as long as wide. Dorsal tooth moderately developed, anteriorly directed, its tip at 83-87\% from base of stoma. Vertical subventral plates with denticles arranged as $3: 3,3: 4,2: 4$ on two plates in three females examined. The denticles near the base of vertical plates distinctly larger than the upper ones, rather a gradual decrease in size from lower to upper ones. Oblique subventral walls of buccal cavity with two foramina each. Nerve

Table 2. Measurements of A ctus salvadoricus (all measurements in $\mu \mathrm{m}$ ).

\begin{tabular}{|c|c|c|c|}
\hline \multirow[t]{2}{*}{ Characters } & \multirow{2}{*}{$\begin{array}{l}\text { Salvador population } \\
\text { Baqri \& Jairajpuri, } 1974 \\
n=4\end{array}$} & \multicolumn{2}{|c|}{ Japan Population } \\
\hline & & $\begin{array}{l}\text { Females } \\
n=3\end{array}$ & $\begin{array}{c}\text { Juvenils } \\
n=3\end{array}$ \\
\hline Body length & 850-1210 $\quad 1$ & $1168-1268$ (1215) & $1074-1118$ (1102) \\
\hline Body width & - & $45.0-47.5$ (46.1) & 37.1-37.9 (37.9) \\
\hline a & $20-24$ & $25.6-26.8(26.3)$ & $28.9-29.3(29.0)$ \\
\hline b & $3.5-4.3$ & $3.7-3.9 \quad(3.8)$ & $3.7-3.9 \quad(3.8)$ \\
\hline c & $17-20$ & $21.0-24.3(22.8)$ & $21.5-23.7(22.4)$ \\
\hline$c^{\prime}$ & $1.8-2.4$ & $1.9-2.2 \quad(2.1)$ & $1.9-2.2 \quad(2.1)$ \\
\hline V $(\%)$ & $61-64$ & $62.8-63.9(63.4)$ & - \\
\hline G1 & - & $13.2-15.7(14.5)$ & - \\
\hline G2 & - & $9.4-14.7 \quad(11.3)$ & - \\
\hline Lip region width & $23-24$ & $23.5-24.5 \quad(24.2)$ & $20.5-21.3(20.8)$ \\
\hline Lip region height & $8-9$ & $6.0-6.3 \quad(6.2)$ & $5.1-5.5 \quad(5.4)$ \\
\hline Buccal cavity length & $24-26$ & $27.6-27.7(27.7)$ & $23.3-23.7(23.6)$ \\
\hline Buccal cavity width & $14-15$ & $13.5-15.1 \quad(14.3)$ & $11.1-12.2$ (11.6) \\
\hline $\begin{array}{l}\text { Position of dorsal tooth } \\
\text { from base of stoma }\end{array}$ & 18 & $20.4-20.9(20.6)$ & $17.4-18.2(17.8)$ \\
\hline Nerve ring from anterior end & $78-99$ & $104-115$ (110) & $89-96 \quad(92)$ \\
\hline Neck length & - & $300-326 \quad(316)$ & $290-294 \quad(292)$ \\
\hline A nterior genital branch & - & $118-200 \quad(158)$ & - \\
\hline Posterior genital branch & - & $118-183 \quad(150)$ & - \\
\hline Vulva position from anterior end & - & $734-810$ (771) & - \\
\hline Rectum length & $20-23$ & $22.1-23.7(22.6)$ & $20.5-21.3(21.0)$ \\
\hline A nal body diameter & - & $24.8-27.6(25.8)$ & $22.5-24.9(23.7)$ \\
\hline Tail length & $51-61$ & $52.2-55.7(53.4)$ & 47.1-52.1 (49.4) \\
\hline
\end{tabular}



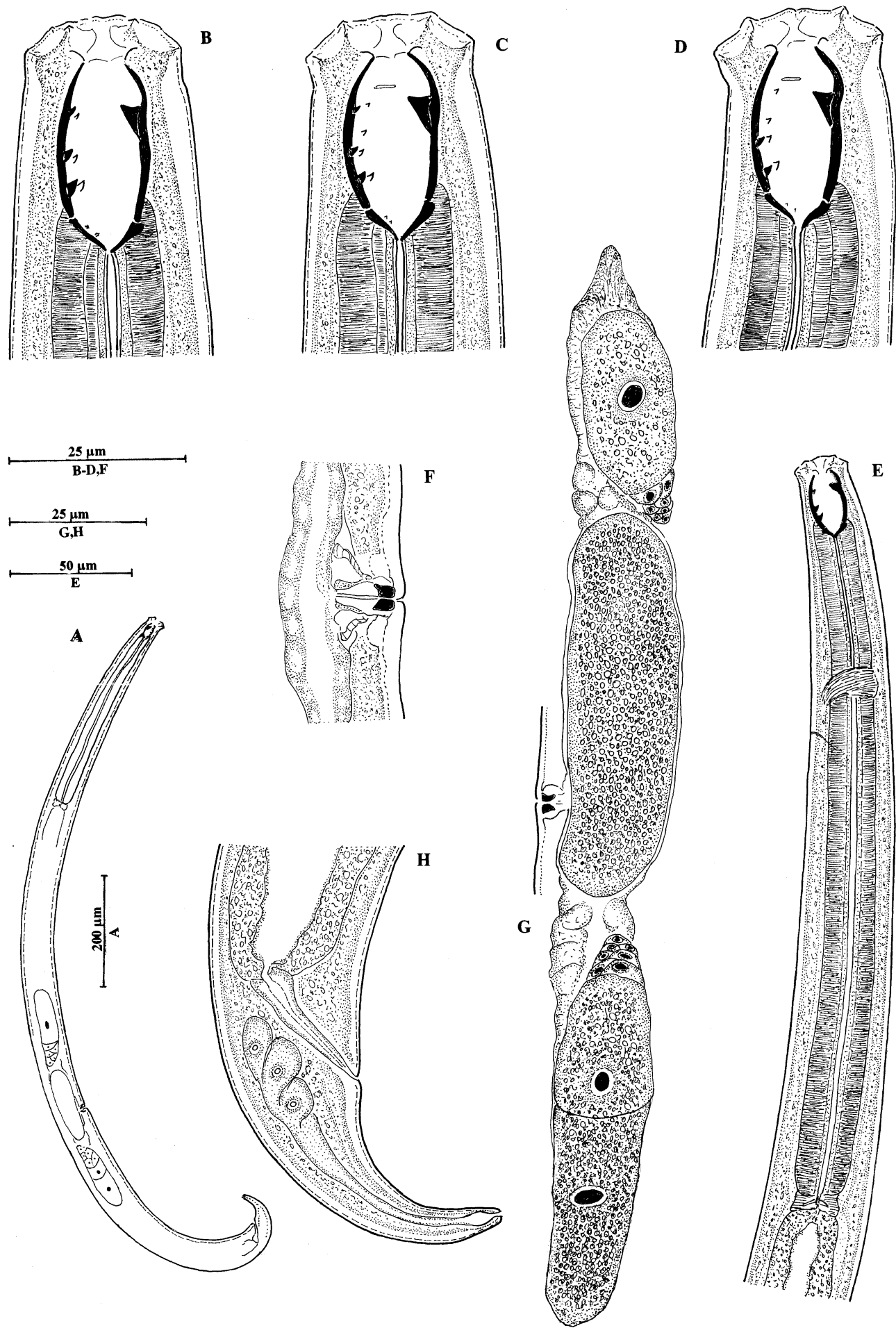

Fig. 2. Actus salvadoricus. A: Entire female, B-D: Head ends showing teeth arrangements and amphid position, E: A nterior region, F: Vulval region, G: Female genital system, H: Posterior end. 

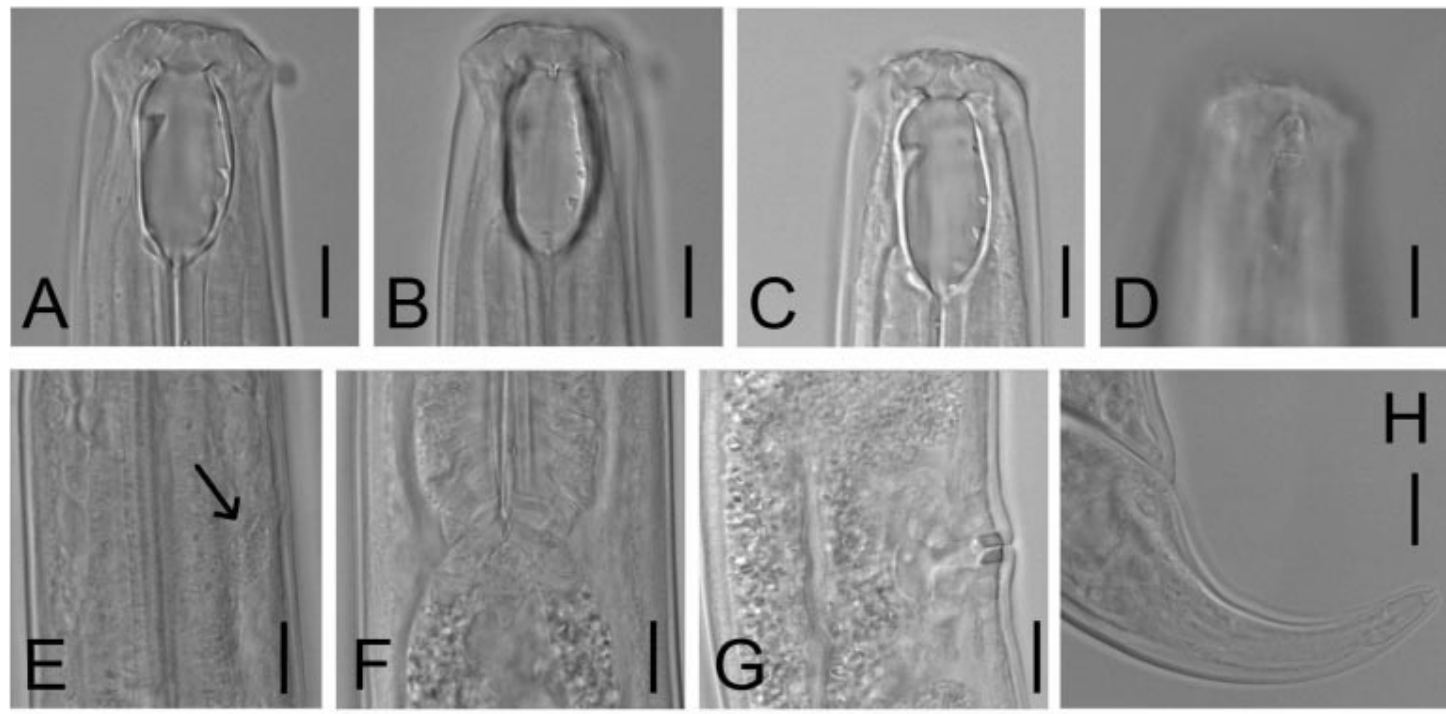

Fig. 3. A ctus salvadoricus. A : Head ends showing dorsal tooth, B-C: Head ends showing denticle arrangements (through focus series), D: Head end showing amphid position, E: Excretory cell (arrow), F: Oesophago-intestinal junction, G: Vulval region, $\mathrm{H}$ : T ail showing spinneret. Scale bar is $10 \mu \mathrm{m}$.

ring at $32-35 \%$ of neck length from anterior end. Excretory pore distinct, at 35-37\% of neck length from anterior end. A n excretory cell observable, directly connected to the excretory pore. Orifice of pharyngeal glands located as follows: dorsal 136-141 $\mu \mathrm{m}$ from anterior end; first pair of subventrals $64-71 \mu \mathrm{m}$ from the orifice of dorsal one; second pair 65-74 $\mu \mathrm{m}$ from the first pair. Pharyngo-intestinal junction nontuberculate. Genital system amphidelphic; both sexual branches almost equally developed. Ovary reflexed, measuring 69-138 $\mu \mathrm{m}$ (anterior) and 115-157 $\mu \mathrm{m}$ (posterior) with oocytes arranged in a single row except near tip. Oviduct with distinct pars dilatata. Uterus filled with single oocyte, measuring 108-121 x 36-29 $\mu \mathrm{m}$ in two specimens. Sphincter indistinct. No trace of sperms either in uterus or oviduct. Vagina extending about one-fourth of the corresponding body width; pars proximalis vaginae 6.5-7.0 $\mu \mathrm{m}$ long, encircled by circular muscles; pars refringens vaginae with triangular sclerotization, each measuring 3.5-4.0 × $2.5 \mu \mathrm{m}, \mathrm{cw} 5.0$ $6.0 \mu \mathrm{m}$; pars distalis vaginae $2.0 \mu \mathrm{m}$. Rectum 0.8 -
0.9 times the anal body width long. Tail elongate-conoid, ventrally arcuate, 1.9-2.2 anal body widths long. Caudal glands tandem; spinneret terminal.

Juveniles $(n=3)$ : Similar to female in general morphology. Vertical subventral plates of buccal cavity with denticles arranged as 2:3, 3:3, 3:4. Caudal glands and spinneret well developed.

Male: Not found.

Specimens examined: Three females and 3 juveniles collected from soil around trees from evergreen forest, Y ona Field, Subtropical Field Sciences Center, Faculty of Agriculture, University of the Ryukyus, Okinawa Pref. Okinawa Island, Japan (29. xi. 2006, M. Olia leg.). Specimens are deposited at the nematode collection of the Department of Zoology, A ligarh Muslim University, India.

Diagnosis and relationship: Female length 1.2-1.3 mm; stoma $13-15 \times 27-28 \mu \mathrm{m}$; dorsal tooth apex at $83-87 \%$ of stoma length; vulva at $62-64 \%$; gonads paired; no vulval papillae; tail elongate conoid, ventyrally arcuate, 1.9-2.2 anal 


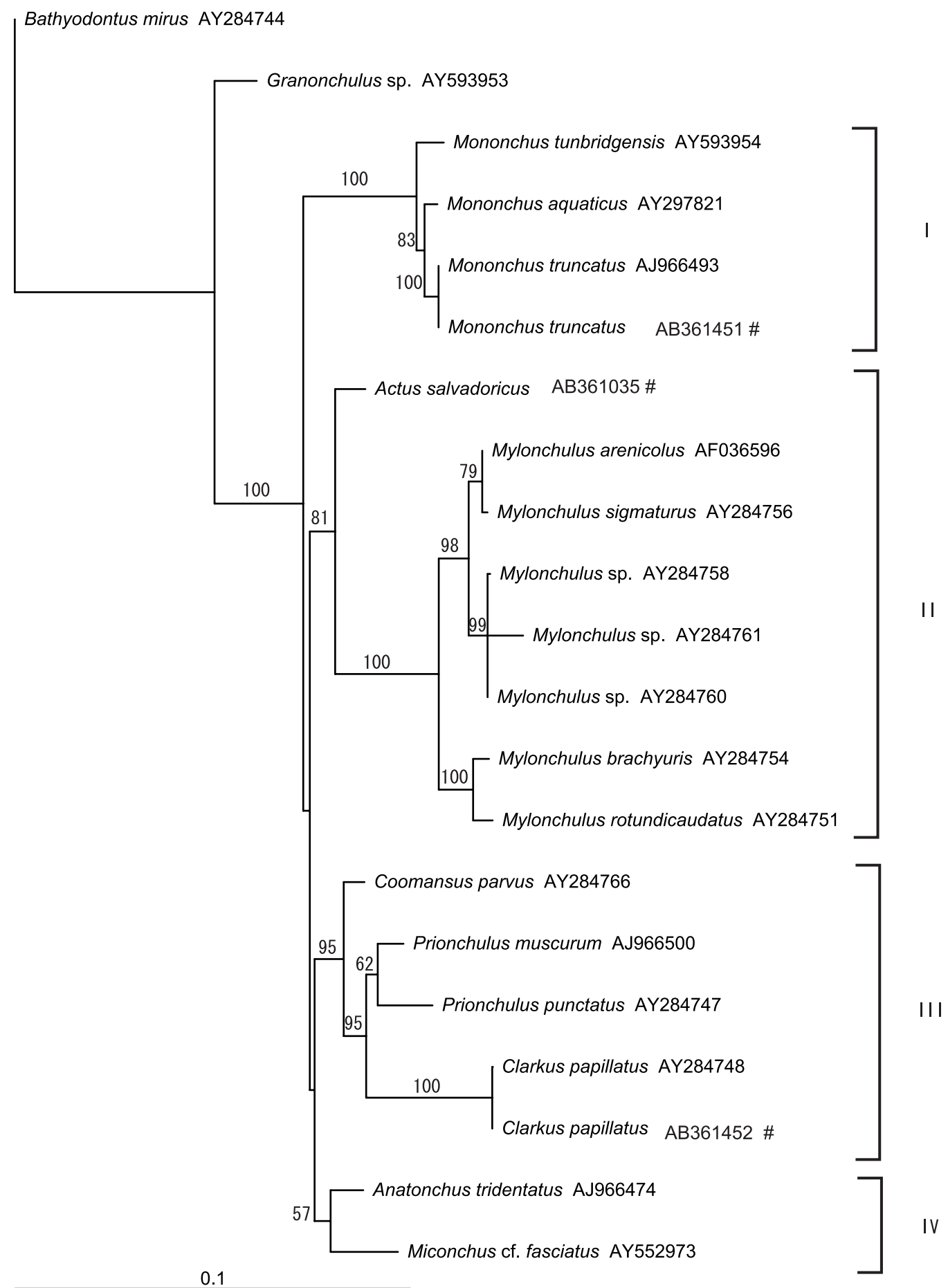

Fig. 4. Maximum likelihood tree obtained from heuristic search of 185 rDNA sequence data for the known and newly sequenced operational taxonomic units in the suborder Mononchina. Bootstrap support values for clades occurring at $>50 \%$ frequency are shown. A numerical sign indicates sequence data is from this study. See text for details of $M L$ analysis. 
body widths long; caudal glands well developed with distinct terminal opening. Male unknown.

Our three specimens have anteriorly positioned amphids, anteriorly directed and moderately developed dorsal tooth, longer tail and pronounced spinneret, which fully agree with the description of $A$. salvadricus provided by Baqri and Jairajpuri 1974. It can be pointed that their denticles show a gradual decrease in size from lower to upper. A ctus salvadricus Baqri and Jairajpuri, 1974 closely resembles A. minutus in the amphid position (at the level of dorsal tooth apex) and body dimensions, but is distinguished in the anterior position of amphids (more anterior), the shape of dorsal tooth (distinctly anteriorly directed with anterior wall concave), and in having a comparatively longer tail with a pronounced terminal opening of caudal glands. From A. nanurus Siddiqi, 1984, it differs in having comparatively longer and slender body (vs. 0.9-1.1 mm; $a=22-28$ ), and longer tail (vs. $c=33-$ 57; $\left.c^{\prime}=0.8-1.3\right)$. From $A$. neocaledonensis $Y$ eates, 1992, the species differs in having comparatively smaller body size (vs. $L=1.21-1.47$ $\mathrm{mm}) ;$ smaller stoma size (vs. 31-36 $\mu \mathrm{m}) ;$ dorsal tooth more anteriorly placed (vs. 55-70\% of stoma length); comparatively posterior vulva (vs. $V=60-63)$, and conspicuous caudal gland opening (vs. caudal gland opening obscure).

Molecular profiles and phylogeny:

All unique sequences acquired in this study were deposited in GenBank by Accession Nos: A B361035 (SSU) and A B 361450 (ITS) for A cutus salvadoricus; $A B 361451$ (SSU) for Mononchus truncatus; A B 361452 (SSU) for Clarkus palliatus (Fig. 4, \# codes).

Sequences were compared with existing sequences in GenBank database via BLAST pairwise searches to determine the nearest match on the likelihood tree (Fig. 4). The nearly complete SSU sequences obtained from all the included taxa consisted of 1,766 (A natonchus tri- dentatus) to 1591 (M iconchus cf. faciatus) bp and the edited ClustalX alignments contained 1498 bp.

The best-fit substitution model for the ML analysis under AIC was GTR $+\Gamma+1$, that is, the general timereversible model with a gamma correction for variable rates among sites (shape parameter $=0.7267$ ) and with incorporating a proportion of invariant sites (proportion = 0.559). The $M L$ analysis found the optimal tree (- InL = 4487.39836) (Fig. 4). The bootstrap support for the ML tree is shown in Fig. 4.

The MP analysis using $18 \mathrm{~S}$ rDNA sequences also conducted (Data not shown). The MP analysis revealed 12 equally most parsimonious trees with a length of 420 steps (98 characters are parsimony-informative, $\mathrm{Cl}$ (consistency index) $=0.748, \mathrm{RI}$ (retention index) = 0.836). All optimal trees are nearly identical in topology except for several terminal differences which resulted in trichotomies in the strict consensus tree. The bootstrap support for each branch of the consensus tree shows that almost all clades are statistically reliable. The consensus tree shows that there was no difference with the $M L$ tree (especially for the clade which includes the genus A ctus) except for some outer clades with lower bootstrap values.

The ML tree (Fig. 4) shows four major clades in our studied taxa. Members of the genus $\mathrm{M}$ ononchus (Clade I) make an independent clade with high bootstrap support while $M$ ylonchulus species, along with Actus salvadoricus as a sister group, form another clade (Clade II). The third clade (Clade III) includes members of the subfamily Prionchulinae like Coomansus parvus, Clarkus papilatus, Prionchulus muscurum and Prionchulus punctatus, and the last clade (Clade IV) is composed of the tuberculate mononchs comprising A natonchus tridentatus and $\mathrm{M}$ iconchus sp. The present $18 \mathrm{~S}$ rDNA sequence data set clearly shows that the genus 
A ctus stands neither with Prionchulinae nor with Mononchus spp. and is considered closely related to M ylonchulus spp. within Clade II. Our hypothesis of the phylogenetic position of the genus Actus is corroborated by relatively high bootstrap support values for these major clades.

\section{DISCUSSION}

Actus salvadoricus, a valid species

Baqri and Jairajpuri (1974) proposed the genus Actus for Sporonchulus minutus (Mulvey, 1963) and a new species, A. salvadoricus which they described from El Salvador in Central A merica. It was stated that members of Actus have on each subventral wall a single row of few (4-5) denticles which is in contrast to other species of Sporonchulus (Cobb, 1913) Pennak, 1953 where additional rows of irregularly scattered denticles are present. They (I.c.) differentiated it from Prionchulus in the absence of longitudinal rib along which the subventral denticles are arranged, and placed it under Mononchidae Chitwood, 1937 close to the genus Prionchulus (Cobb, 1916) Wu and Hoeppli, 1929. Subsequently, Jairajpuri and Khan (1982) placed it under Prionchulinae Andrássy, 1976. Siddiqi (1984) described a third species, A . nanurus from Fiji and argued against placing Actus in Prionchulinea, considered it to be more close to Sporonchulus and a member of the subfamily Mononchinae Chitwood, 1937. Y eates (1992) added a further new species $A$. neocaledonensis from New Caledonia.

Baqri and Jairajpuri (1974) described A. salvadoricus from El Salvador and differentiated it from A. minutus (Mulvey, 1963) Baqri and Jairajpuri (1974) in the anterior position of amphids, the shape of dorsal tooth, and in having a comparatively longer tail with a pronounced terminal opening of caudal glands. Mulvey (1963) described A. minutus (= Sporonchulus minutus) from Saipan based on three females and three juveniles. As per his description and figure the dorsal tooth is medium sized and opposed by longitudinal rows of denticles. The posterior two denticles are nearly basal and larger than other eight, i.e. 4+1 (5) denticles are on each plate and an obscure terminal opening on tail. A ndrássy (1993) synonymized $A$. salvadoricus with $A$. minutus giving the reason that $A$. salvadoricus differs from A . minutus only in location of amphids which lie a little more anterior. He did not mention the difference in the shape of dorsal tooth or the pronounced terminal opening of the caudal glands. The dorsal tooth in our specimens as well as in original description of $A$. salvadoricus (fig. $1 B$ of Baqri and Jairajpuri (1974)), is distinctly anteriorly directed with its anterior wall becoming concave (vs. the dorsal tooth not anteriorly directed, its front edge straight, perpendicular to the body axis in A. minutus (Fig. 10 of Mulvey (1963)). A nother important difference between the two species is in the number of denticles on two subventral walls which is five on each plate in A. minutus, whereas, it is five on one plate and four on the other in type specimens (Fig. $1 \mathrm{C}$ of Baqri and Jairajpuri (1974)). In our three specimens, the denticles on two plates were 3:3, 3:4, $2: 4$, i.e. they have tendency of having different number of denticles on the subventral walls. In A. minutus the posterior denticle is larger than the other four. In A. salvadoricus also the posterior denticle is distinctly larger than the others where we see a gradual decrease in size from lower to upper. This is not the case with A. minutus where all the denticles are of same size or rather the upper two are larger than the lower two if we see the Fig.10 of Mulvey (1963). The most striking difference between the two species is the terminal caudal opening which is well developed in A. salvadoricus (Fig. IF of Baqri and Jairajpuri (1974) as well as in all our specimens from Japan) whereas it is obscure in $A$. 
minutus. On the basis of above morphological differences we consider $A$. salvadoricus a valid species.

Phylogenetic analysis:

We recognized four major clades of mononchs in our study, which mostly were in accordance with their morphological classification (T able 3 and Fig. 4). Clade I of our ML tree consisted of the members of genus Mononchus. Clade II mainly consisted of the members of genus M ylonchulus with Actus salvadoricus as a sister group. These two genera belong to family M ylonchulidae. Clade III were made of Genera Prionchulus, Clarkus and Coomansus, which belong to Family Mononchidae, Subfamily Prionchulinae. Members of Family A natonchidae, Subfamily A natonchinae, A natonchus and $M$ iconchus were in the Clade IV.

The results of our study also indicate two groups under Mononchidae viz., Mononchinae represented by the genus $M$ ononchus (clade I) and Prionchulinae (clade III). Members of Prionchulinae have two apomorphies, possession of a ridge on subventral plate and absence of caudal glands and spinneret whereas, $M$ ononchinae lack ridge on subventral plate and have well developed caudal glands and spinneret.

Baqri and Jairajpuri (1974) while discussing the systematic position of the genus Actus, wrote "the differences from Sporonchulus are considered to be of more fundamental nature and thus the new genus has been removed from this group (i.e., Sporonchulinae, Mylonchulidae Jairajpuri, 1969), and placed under the family M ononchidae Chitwood, 1937 close to the genus Prionchulus". As per Jairajpuri (1969) Mylonchulidae is divided into two subfalilies, viz, Mylonchulinae Jairajpuri, 1969 with the genera Mylonchulus (Cobb, 1916) A Itherr, 1953 and Polyonchulus Mulvey and Jensen, 1967, and the subfamily Sporonchulinae Jairajpuri, 1969 with the genera Sporonchulus (Cobb, 1917) Pennak, 1953, Granonchulus Andrássy, 1958, Prionchuloides Mulvey, 1963, Judonchulus A ndrássy, 1958, and Brachonchulus A ndrássy, 1958. Jairajpuri and Khan (1982) placed Actus in the subfamily Prionchulinae A ndrássy, 1976 under the family Mononchidae. Siddiqi (1984) considered A ctus close to Sporonchulus under the subfamily Mononchinae. It means, he did not accept the two subfamilies Mylonchulinae and Sporonchulinae under Mylonchulidae and considered Sporonchulus under Mononchidae rather than Mylonchulidae. Andrássy (1993) accepted only two families under Mononchoidea, viz., Mononchidae with the subfamilies Mononchinae Chitwood, 1937 and Cobbonchinae Jairajpuri, 1969 and Mylonchulidae with the single subfamily Mylonchulinae. He grouped Actus under the subfamily Mononchinae close to Prionchulus, Clarkus, Sporonchulus etc. The present analysis of 18SrDNA sequence indicating close relationship of $A$ ctus with $M$ ylonchulus places it in the family Mylonchulidae Jairajpuri, 1969. The nature of its buccal dentation, the subventral denticles arranged in a row in Actus while irregularly scattered in Sporonchulus, suggests that A ctus has close resemblance with Sporonchulus as also indicated by Siddiqi (1984) rather than Prionchulus. Unfortunately sequence data is not available for any species of Sporonchulus nor we were able to collect specimens representing this genus for our study but it is most likely that Sporonchulus also belongs to this group as originally conceived by Jairajpuri (1969) with two subfamilies, viz., Mylonchulinae and Sporonchulinae under Mylonchulidae.

The genus Granonchulus has been assigned morphologically in Mononchoidea, Mylonchulidae, Sporonchulinae (Jairajpuri, 1969). In our morphological study it is shown that the genus Actus has close resemblance with 
genus Sporonchulus. On the other hand, genus Granonchulus occupied a quite different position in the phylogenetic tree using DNA sequences. Further study is needed to clarify the relationship between the genera Actus and Granonchulus.

\section{A CKNOW LEDGE MENTS}

The first author is thankful to Japan Society for the Promotion of Science for awarding postdoctoral fellowship and Shahrekord University, Shahrekord, Iran, to carry out research in Nematology and Soil Zoology Lab., National Institute for A gro-Environmental Sciences, Japan. The authors are thankful to Prof. M. Shamim Jairajpuri , A ligarh Muslim University , Aligarh, India, for his comments on the manuscript. We are also grateful to Dr. M. Kheirandish, National Institute for AgroBiological Sciences, Japan, for his valuable helps and suggestions during this study.

\section{LITERATURE CITED}

Andrássy, I. (1993) A taxonomic survey of the family Mononchidae (Nematoda). A cta Zoologica Hungarica 39, 13-60.

Baqri, S. Z. and Jairajpuri, M. S. (1974 ["1973"]) Studies on M ononchida. V. The mononchs of El Salvador with description of two new genera, Actus and Paracrassibucca. Nematologica 19, 326-336.

Blaxter, M . L., De Ley, P., Garey, G. R., Liu, L. X., Scheldeman, $P$. , Vierstraete, $A$., V anfleteren, J. R., Mackey, L. Y., Dorris, M., Frisse, L. M., Vida, J. T. and Thomas, W. K. (1998) A molecular evolutionary framework for the phylum Nematoda. Nature 392, 71-75.

Cobb, N. A . (1918) Estimating the nematode population of the soil. A gricultural Technology Circular 1, Bureau of Plant Industry, US Department of A griculture, Batesville, 48 pp.
Curran, J., Driver, F., B allard, J. W. O. and Milner, R. J. (1994) Phylogeny of metarhizium: analysis of ribosomal DNA sequences data. Mycological Research 98, 547-552.

Delong, E. F. (1992). A rchaea in coastal marine environments. Proceedings of the National A cademy of Science United States of A merica 89, 5685-5689.

Hills, D. M. and Dixon, M. T. (1991) Ribosomal DNA : molecular evolution and phylogenetic inference. The Quarterly Review of Biology 66, 411-453.

Imamura, S. (1931) Nematodes in the paddy field, with notes on their populations before and after irrigation. The Journal of the College of A griculture, Imperial University of T okyo 11, 193-240.

Jairajpuri, M. S. (1969) Studies on M ononchida of India I. The genera Hadronchus, Iotonchus, and $\mathrm{M}$ iconchus and a revised classification of Mononchida, new order. Nematologica 15, 557-581.

Jairajpuri, M. S. and Khan, W. U. (1982) Predatory nematodes (Mononchida) with special reference to India. A ssociated Publishing Co., New Delhi, 131 pp.

Kaburaki, T. (1933) Notes on the fauna of Oze district. In: Oze Ten-nen Kinenbutsu Chosa Hokoku (Census Report of Oze, the Natural Monument), Ministry of Education, Tokyo, 70-94. (in Japanese).

Khan, Z. and A raki, M. (2002). A new and two first recorded species of Mononchids (Nematoda: Mononchida) from Japan. Nematologia Mediterranea 30, 167-173.

Khan, Z., A raki, M. and Bilgrami, A . L. (2000) lotonchus sagaensis sp. n., I. arcuatus sp. $n$. and Miconchus japaonicus sp. n. (Nematoda: Mononchida) from Japan. International Journal of Nematology 10, 143-152.

Meldal, H. M., Debenham, N. J., De Ley, P., Irma T., V anfleteren, J. R., V ierstraete, A. R., B ert, 
W., Borgonie, G., Moens, T., T yler, P. A ., A usten, M. C., Blaxter, M. L., Rogers, A. D. and Lambshead, P. J. D. (2007) A n improved molecular phylogeny of the Nematoda with special emphasis on marine taxa. Molecular Phylogenetics and Evolution 24, 622-636.

Mulvey, R. H. (1963) The M ononchidae: a family of predaceous nematodes V. Genera Sporonchulus, Granonchulus, and Prionchuloides n. gen. (Enoplida: M ononchidae). Canadian Journal of Zoology 41, 763-774.

Mulvey, R. H. and Jensen, H. J. (1967) The Mononchidae of Nigeria. Canadian Journal of Zoology 45, 667-727.

Nakazawa, K. (1999) Morphological characteristics and ecological survey of three species of the genus Mononchus from wet soil in Gunma prefecture. Japanese Journal of Nematology 29(2), 16-23.

Orui, Y . (1996) Discrimination of the main Pratylenchus species (Nematoda: Pratylenchidae) in Japan by PCR-RFLP A nalysis. Applied Entomology and Zoology 31, 505514.

Page, R. D. M. (1996) TREEVIEW : A n application to display phylogenetic trees on personal computers. Computer A pplications in the Biosciences 12, 357-358.

Page, R. D. M. and Holmes, E. C. (1998) Molecular Evolution: A Phylogenetic A pproach. Blackwell Science Ltd., Oxford, 221 pp.

Posada, D. and Crandall, K. A . (1998) Modeltest: testing the model of DNA substitution. Bioinformatics 14, 817-818.

Seinhorst, J. W . (1962) On the killing, fixation and transferring to glycerin of nematodes. Nematologica 4, 67-69.

Shishida, Y. (1998) Nematodes (included in Soil fauna of Mt. T sukuba (T amura, $H$. et al., authers). In: The 1st General Research Report of the Ibaraki Nature Museum-
Nature in the Prefectural Southern District Including $\mathrm{Mt}$. Tsukuba and Lake Kasumigaura-, Ibaraki Nature Museum, Iwai, 295-296. (in Japanese).

Siddiqi, M.R. (1984) Four new genera and four new species of mononchs (Nematoda). Pakistan Journal of Nematology 1, 1-13.

Southey, J. F. (ed.) (1970) Laboratory Methods for Work with Plant and Soil Nematodes. Her Majesty's Stationary Office, London, 148pp.

Swofford, D. L. (2002) Phylogenetic A nalysis Using Parsimony (and Other Methods) Version 4. Sinauer A ssociates, Sunderland, Massachusetts, 221pp.

Thompson, J. D., Gibson, T. J., Plewniak, F., Jeanmougin, F. and Higgins, D. G. (1997) The ClustalX windows interface: flexible strategies for multiple sequence alignment aided by quality analysis tools. Nucleic A cids Research 24, 4876-4882.

V anfleteren, J. R., Blaxter, M. L., T weedie, S. A. R., T rotman, C., Lu, L., Van Heuwaert, M. L. and Moens, M. (1994) Molecular genealogy of some nematode taxa as based on cytochrome $c$ and globrin amino acid sequences. Molecular Phylogenetics and Evolution 3, 92-101.

V rain, T. C., W akarchuk, D. A ., Levesque, A. C. and Hamilton, R. I. (1992) Intraspecific rDNA restriction fragment length polymorphism in the Xiphinema americanum group. Fundamental and Applied Nematology 15, 563-573.

Y eates, G. W . (1992) N ematodes from new Caledonia. I. Introduction and Mononchoidea. Fundamental and A pplied Nematology 15, 101-126.

Y okoo T. and Koga S. (1966) On the nematodes found from the soils dug around the roots of A zalea nurseries for sale: One sample of the propagation of the more important plant 
parasitic nematodes by selling of the nurseries. Agriculture Bulletin of Saga
University, Saga, Japan 23, 7-15.

Received September 6, 2007 